\title{
Satellites reveal extent of groundwater loss in western United States
}

Drought-stricken Colorado River basin is drawing down underground supplies.

\section{Mark Zastrow}

25 July 2014

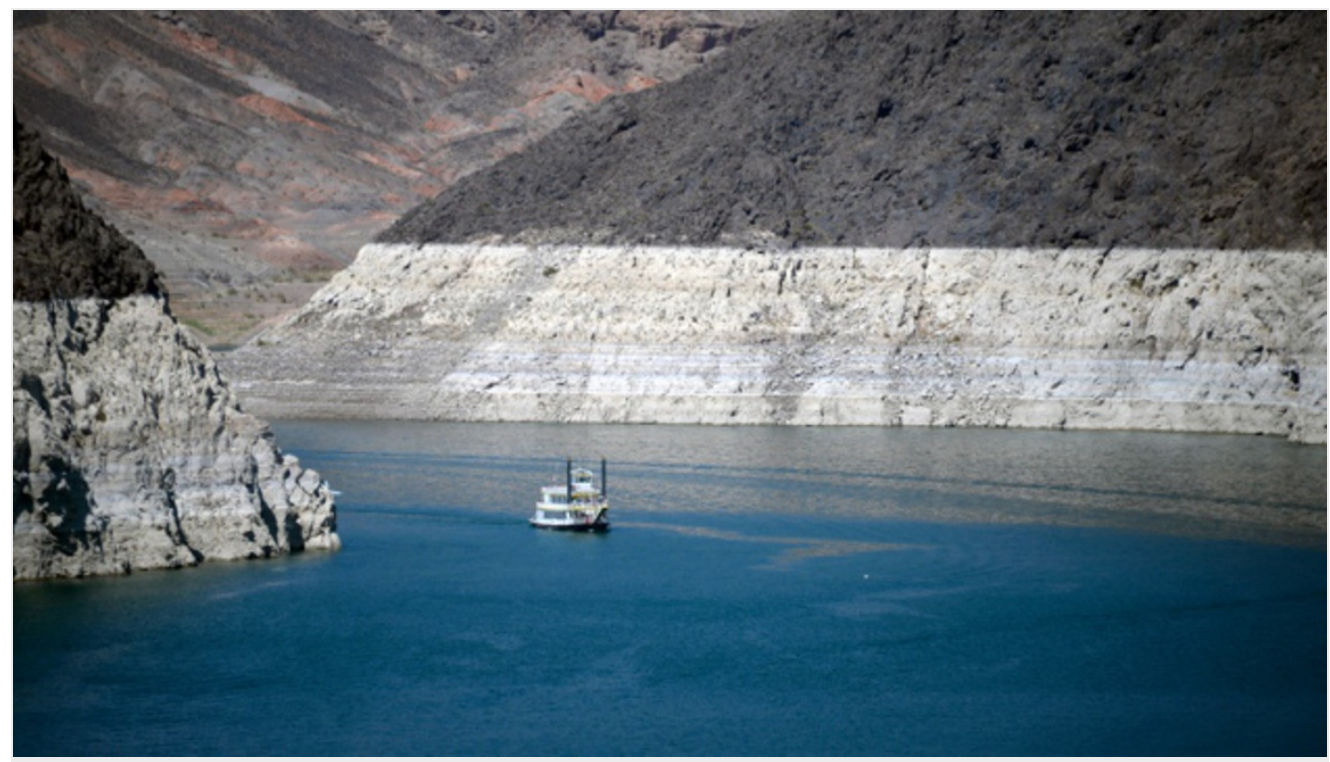

Gene Blevins/ZUMA/Alamy

A white 'bathtub ring' around Lake Mead in Nevada shows how much water levels have dropped.

A 14-year drought in the southwestern United States has drained reservoirs such as Nevada's Lake Mead to record lows. But satellite measurements show that the losses are even greater underground.

Communities in the Colorado River basin are rapidly depleting crucial groundwater to refill their reservoirs and irrigate cropland, researchers reported on 24 July in Geophysical Research Letters ${ }^{1}$. Groundwater is like a bank account, and it is now in overdraft to the tune of 5.6 trillion litres a year, the team says.

To track groundwater losses, researchers used data from the Gravity Recovery and Climate Experiment (GRACE), a pair of satellites operated by NASA and the German Aerospace Centre (DLR) that measure variations in the gravitational pull of Earth. The team found that from December 2004 to November 2013, the Colorado River basin — which supplies roughly 40 million people in seven US states — lost roughly 65 trillion litres of fresh water. To determine how much of that was groundwater, they subtracted out water lost from surface reservoirs and soil. 
Nevada and Arizona. "It was way more than we ever thought," says study co-author Jay Famiglietti, a water-cycle scientist at NASA's Jet Propulsion Lab in Pasadena, California.

\section{Groundwater overdraft}

Researchers have been tracking the basin's groundwater supply using measurements of well-water levels for some time, and the satellite data are in line with those. But well data measure water levels at specific points, whereas GRACE can directly measure the mass of water over an entire region, says John Wahr, a geophysicist at the University of Colorado at Boulder.

The results confirm that groundwater overdraft is a problem throughout the western United States, says Jay Lund, a water-resource engineer and director of the Center for Watershed Sciences at the University of California, Davis.

The problem is magnified by the fact that the groundwater is being removed from the ground faster than nature can replenish it. And as it dwindles, the cost to pump rises because the water has to come from greater depths. "At some point, it becomes more costly than it's worth," says Lund.

Because most irrigation in the Colorado River basin relies on groundwater, agriculture is most likely to suffer as the supply is depleted, the authors say. Rural communities that rely on well water are also at risk, Lund points out, and there are environmental threats, too. Overdrawing groundwater dries up the springs that feed pool ecosystems, stranding endangered species such as the desert pupfish (Cyprinodon macularius).

Ultimately, Famiglietti says, his team hopes to produce higher-resolution data on groundwater depletion to help guide local water managers.

Nature | doi:10.1038/nature.2014.15623

\section{References}

1. Castle, S. L. et al. Geophys. Res. Lett. http://dx.doi.org/10.1002/2014GL061055 (2014).

\section{SPRINGER NATURE}

